\title{
KERAGAAN GENETIK IKAN NILA GIFT BERDASARKAN POLIMORFISME MITOKONDRIA DNA D-LOOP
}

\author{
Estu Nugroho, Ani Widiyati, Imron, dan Tutik Kadarini
}

\begin{abstract}
ABSTRAK
Variasi genetik beberapa ras ikan nila yang digunakan dalam budi daya telah diteliti dengan menggunakan polimorfisme mitokondria DNA D-loop. Enam komposit haplotipe terdeteksi dengan menggunakan 3 enzim restriksi yaitu Mbol, Haell, dan Hinfl pada sekuens D-loop. Jumlah rata-rata restriction site adalah 3,3 . Tidak terdapat perbedaan nyata secara genetik yang diamati antara populasi tilapia yang diuji.
\end{abstract}

ABSTRACT: Genetic polymorphism of GIFT tilapia based on the mitochondria D-loop markers. By: Estu Nugroho, Ani Widiyati, Imron, and Tutik Kadarini

Genetic variability of tilapia used as seed in aquaculture was examined using polymorphism of the mitochondria DNA (MtDNA) D-loop markers. Six composite haplotypes were detected using digestion of D-loop sequences with three endonucleases: Mbol, Haell, and Hinfl. The average restriction site number per enzyme was 3.3. No significant genetic difference was observed among the tilapia populations

\section{KEYWORDS: genetic polymorphism, GIFT tilapia, MtDNA D-joop}

\section{PENDAHULUAN}

Dewasa ini budi daya ikan nila telah berkembang pesat di petani. Budi daya intensif ikan telah dilakukan di keramba jaring apung di Waduk Saguling, Cirata, dan Jatiluhur (Jawa Barat); Waduk Kedungombo dan Gajah Mungkur (Jawa Tengah); dan beberapa waduk di Jawa Timur dan Sumatera. Perkembangan yang pesat ini semakin nyata dengan diperkenalkannya ikan nila GIFT (Genetic Improvement of Farmed Tilapia) yang diimpor dari ICLARM, Philipina oleh Balai Penelitian Perikanan Air Tawar Sukamandi pada tahun 1994.

Pengembangan budi daya yang pesat ini harus didukung oleh manajemen pengelolaan yang benar agar dapat sesegera mungkin menanggulangi permasalahan yang mungkin timbul. Salah satu upaya di antaranya adalah dengan melakukan monitoring dan evaluasi terhadap variasi genetik pada tingkat pengguna. Variasi genetik merupakan suatu informasi penting yang dapat digunakan untuk mengevaluasi fitness individu (jangka pendek) dan sintasan dari suatu populasi untuk jangka panjang (Ferguson et al., 1995).

Variasi genetik dapat dievaluasi dengan dua cara yaitu dengan allelic diversity dan heterozygosity. Beberapa metode dapat digunakan untuk mengestimasi tingkat variasi genetik yaitu penggunaan molecular markers (Carvalho \& Pitcher, 1995) termasuk di antaranya adalah mitochondrial DNA (Martin et al., 1992; Park \& Moran, 1995). Pengamatan secara langsung variasi DNA ditemukan bersama dengan isolasi tentang enzim restriksi. Penerapan langsung teknik ini diawali dengan mitochondrial DNA. Teknik ini dapat dilakukan dengan menggunakan sampel dalam keadaan segar, beku ataupun yang disimpan dalam alkohol (Ward \& Grewe, 1995; Nugroho et al., 1997).

Penelitian ini bertujuan mengevaluasi variasi genetik dari beberapa populasi ikan nila GIFT yang telah digunakan dalam budi daya untuk mendapatkan informasi tentang status genetik ikan nila di petani, dan membandingkannya pula dengan jenis ikan nila yang pernah didatangkan ke Indonesia pada tahun 1969.

\section{BAHAN DAN METODE}

\section{Ikan Uji}

Ikan uji yang digunakan dalam penelitian ini adalah ikan nila GIFT yang berasal dari Sukamandi, Sukabumi, Jatiluhur, dan Cirata serta sebagai kontrol digunakan ikan nila 1969 yang diperoleh dari Danau Tempe, Sulawesi Selatan.

\section{Ekstraksi DNA}

DNA ikan diekstraksi dari potongan sirip dengan menggunakan metode standar phenol-chloroform (Nugroho et al., 1997) sebagai berikut; $5-10 \mathrm{mg}$ potongan sirip ikan dimasukkan ke dalam tabung 1,5 $\mathrm{mL}$ yang telah berisi $700 \mathrm{~mL}$ larutan lisis $(10 \mathrm{mM}$ Tris$\mathrm{HCl}, \mathrm{pH} 7,5 ; 125 \mathrm{mM} \mathrm{NaCl} ; 10 \mathrm{mM}$ EDTA, pH 7,5; $0,5 \%$ SDS; 4 M urea). Kemudian ditambahkan $10 \mathrm{mg} /$ $\mathrm{mL}$ Protein kinase dan diinkubasikan pada suhu $37^{\circ} \mathrm{C}$

\footnotetext{
•) Peneliti pada Balai Penelitian Perikanan Air Tawar, Sukamandi
} 
selama 12-24 jam. Sebanyak $700 \mathrm{~mL}$ larutan $\mathrm{PCl}$ (Phenol, Chloroform, Isoamylalcohol) ditambahkan ke dalam campuran yang telah diinkubasikan, kemudian dikocok selama 5 menit dan disentrifus pada kecepatan 3.000 rpm selama 10 menit. Lapisan supernatannya diambil dan dimasukkan ke dalam tabung baru, dan ditambahkan lagi larutan $\mathrm{PCl}$ sebanyak volume supernatannya. Setelah didapatkan kembali supernatan hasil pemisahan dengan larutan $\mathrm{PCl}$, maka selanjutnya ditambahkan $700 \mathrm{~mL}$ larutan $\mathrm{Cl}$ (Chloroform, Isoamylalkohol) dan dikocok selama 5 menit, kemudian disentrifus pada kecepatan 3.000 rpm selama 10 menit. Pada supernatan yang didapatkan pada tahapan ini ditambahkan $100 \mathrm{~mL} 3 \mathrm{M}$ Natrium Acetate dan $1.000 \mathrm{~mL}$ alkohol absolut (99,5\%); dan disimpan pada suhu $-10^{\circ} \mathrm{C}$ selama 30 menit. DNA diendapkan dengan cara menyentrifus campuran di atas pada kecepatan $5.000 \mathrm{rpm}$ selama 10 menit, kemudian larutan di atasnya dibuang dan DNA dikeringkan di suhu ruangan. Setelah kering ditambahkan 50-100 mL Tris-EDTA (TE) buffer dan disimpan dalam suhu $4^{\circ} \mathrm{C}$ sebelum digunakan pada tahap selanjutnya.

\section{Mitokondria D-loop}

Primer yang digunakan untuk mengamplifikasi sekuense mitokondria D-loop adalah primer LH1509 (CAT ATT AAA CCC GAA TGA TAT TT) dan primer FH 1202 (ATA ATA GGG TAT CTA ATC CTA GTT T). Pengamplifikasian dilakukan menggunakan metode Polymerize Chain Reaction (PCR) dengan komposisi reaksi yang terdiri atas: $10 \mathrm{mM}$ buffer; 0,25 mM dNTP; $6 \mathrm{pmol}$ masing-masing primer, 1 unit tag polimerase dan $10 \mathrm{mg}$ DNA dengan total volume keseluruhannya $50 \mathrm{~mL}$. Cycle PCR yang digunakan dalam amplifikasi adalah satu siklus denaturasi pada suhu $94^{\circ} \mathrm{C}$ selama 4 menit. 30 siklus penggandaan yang terdiri atas suhu $94^{\circ} \mathrm{C}$ selama 1 menit, $48^{\circ} \mathrm{C}$ selama 1 menit, dan $72^{\circ} \mathrm{C}$ selama 1 menit. Selanjutnya satu siklus terakhir pada suhu $72^{\circ} \mathrm{C}$ selama 7 menit. Sekuense MtDNA yang didapat direstriksi dengan menggunakan endonuklease sesuai dengan prosedur standar perusahaan. Hasil restriksi kemudian dipisahkan secara elektroforesis dengan menggunakan gel agarose 1\%-3\% dalam Tris-Boric-EDTA (TBE) buffer dan diamati dengan illuminator (UV) serta di cetak gambarnya dengan polaroid.

\section{Analisis Data}

Untuk mengevaluasi variasi DNA antar populasi ikan tilapia, susunan haplotipe untuk masing-masing enzim restriksi dikumpulkan sebagai komposit haplotipe dan dianalisis dengan menggunakan analisis molekuler varians (AMOVA) dan Fst dalam program ARLEQUIN (Schneider et al., 1996). Diversitas haplotipe atau diversitas genetik dihitung berdasarkan Nei \& Tajima (1981) untuk mengamati tingkat variasi genetik yang ada. Kekerabatan antara haplotipe dilukiskan sebagai filogram, sedangkan kekerabatan antara populasi dianalisis dengan menggunakan jarak genetik dari Nei (1972) dan dilukiskan dengan UPGMA dendrogram dalam program PHYLIP (Felstein, 1993).

\section{HASIL DAN BAHASAN}

Sekuens MtDNA D-loop ikan nila hasil PCR mempunyai panjang sekitar $1.800 \mathrm{bp}$. Dari lima enzim restriksi yang digunakan untuk memotong sekuens tersebut (Rsal, BamH, Mbol, Haelll, dan Hinf); hanya tiga jenis enzim yang mempunyai situs pemotongan yaitu Mbol, HaellI, dan Hinfl. Polimorfisme pola pemotongan didapatkan pada enzim Haelll dan Hinfl. Pemotongan sekuens MtDNA D-loop dengan menggunakan enzim HaellI dan Hinfl menghasilkan tiga jenis pola, sedangkan enzim Mbol hanya mempunyai 1 pola restriksi. Salah satu contoh dari pola pemotongan enzim tercantum pada Gambar 1. Secara keseluruhan terdapat 6 komposit haplotipe yang diidentifikasi berdasarkan 3 jenis enzim restriksi pada sekuens MtDNA D-loop ikan nila yang diamati.

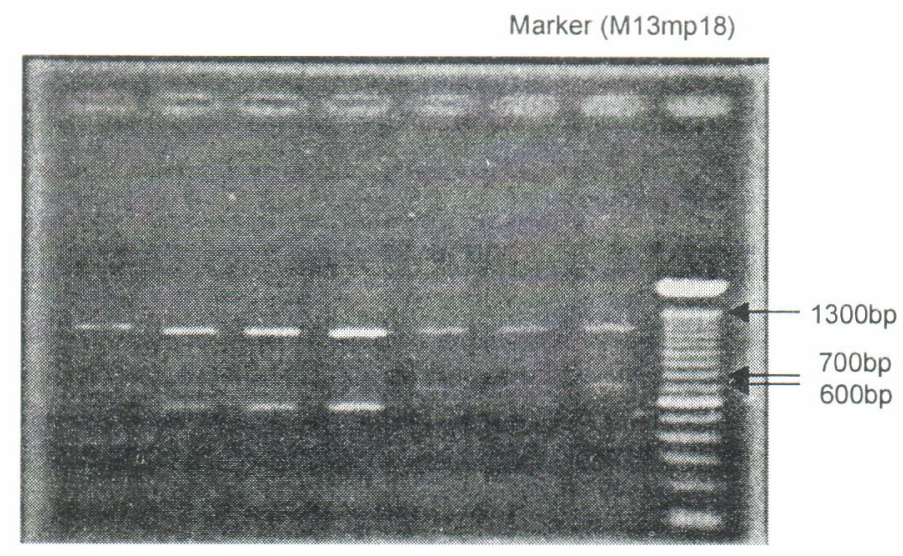

Gambar 1. Contoh pola restriksi mtDNA D-loop ikan nila dengan menggunakan enzim Mbol Figure 1. Restriction type of mtDNA D-loop of tilapia using endonuclease $\mathbf{M b o l}$ 
Panjang sekuens MtDNA D-loop ini setara dengan panjang sekuens daerah yang sama pada beberapa ikan lainnya seperti kingfish, yellow tail, dan red sea bream. Namun demikian, tingkat atau level variasi genetik (yang ditunjukkan dengan jumlah haplotipe maupun diversitas haplotipe) yang ditemui pada ikan nila yang diamati lebih rendah dibandingkan dengan polimorfisme pada ikan budi daya lainnya, terutama ikan laut yang mempunyai jumlah haplotipe berkisar 6-17 dengan nilai diversitas haplotipe antara 0,6-0,9 (Nugroho, 2001). Penyebab rendahnya tingkat variasi genetik ini antara lain karena ikan air tawar mempunyai tingkat migrasi yang lebih rendah, sehingga peluang untuk adanya persilangan dengan jenis atau ras yang lainnya semakin kecil pula. Selain itu, ikan nila yang digunakan merupakan ikan nila GIFT yang merupakan hasil seleksi yang telah dilakukan cukup lama yang mempunyai konsekuensi turunnya variasi genetik yang ada. Lebih jauh dapat dilihat pada perbandingan antara nila GIFT dan nila 1969, di mana nila 1969 tersebut merupakan nila dari perairan alami (Danau Tempe) yang mempunyai variasi lebih besar (Tabel $1)$.

Tingkat variasi haplotipe dipengaruhi oleh asal koleksi ikan nila. Jumlah komposit haplotipe yang dimiliki oleh masing-masing koleksi berkisar antara 1-3. Jumlah yang terkecil diamati pada ikan nila dari Jatiluhur, sedangkan jumlah yang tertinggi terdapat pada ikan nila dari D. Tempe dan Sukamandi. Lebih jauh tercatat bahwa nila D. Tempe didominasi oleh komposit haplotipe 1 dan 4, sedangkan nila dari Sukamandi lebih didominasi hanya oleh komposit haplotipe 1. Secara keseluruhan ikan nila yang diuji mempunyai komposit haplotipe utama yang sama yaitu komposit haplotipe 1 (Tabel 1). Diversitas haplotipe atau gen bervariasi nilainya dari 0 pada ikan nila dari Jatiluhur hingga 0,368 pada ikan nila dari D. Tempe. Secara umum, keseluruhan populasi ikan nila

Tabel 1. Distribusi frekuensi haplotipe dari beberapa koleksi ikan nila GIFT dan nila 69 berdasarkan MtDNAD-loop yang direstriksi dengan menggunakan 3 jenis enzim, Mbol, Haell, dan Hinf

Table 1. Haplotype frequency distribution of GIFT tilapia based on the mIDNA D-loop markers generated by three endonucleases, Mbol, Haelll, and Hinfl

\begin{tabular}{cccccc}
$\begin{array}{c}\text { Haplotipe } \\
\text { Haplotype }\end{array}$ & Sukamandi & Sukabumi & Cirata & Jatiluhur & D. Tempe \\
\hline AAA & 0.857 & 0.917 & 0.857 & 1.0 & 0.789 \\
ABB & 0.071 & 0.000 & 0.000 & 0.000 & 0.000 \\
ABA & 0.071 & 0.083 & 0.000 & 0.000 & 0.000 \\
AAC & 0.000 & 0.000 & 0.000 & 0.000 & 0.158 \\
ACC & 0.000 & 0.000 & 0.000 & 0.000 & 0.053 \\
ACA & 0.000 & 0.000 & 0.143 & 0.000 & 0.000 \\
\hline N-sampel (N-sampel) & 14 & 12 & 7 & 6 & 19 \\
N-Haplotipe (N-haplotype) & 3 & 2 & 2 & 1 & 3 \\
Diversitas genetika (Gene Diversity) & 0.275 & 0.167 & 0.286 & 0.0 & 0.368 \\
\hline
\end{tabular}

yang diuji mempunyai komposit haplotipe utama yang serupa. Ini menandakan bahwa ada kemungkinan ikan tersebut mempunyai sumber genetik yang serupa. Haplotipe 1 dapat ditemukan pada frekuensi yang besar pada setiap populasi, di samping haplotipe 4 yang juga cukup besar dan hanya dapat diamati di populasi ikan nila dari D. Tempe. Jika ikan nila 1969 yang digunakan benar asal-usul sumber genetiknya dari daerah sekitarnya, maka hasil ini cukup mengejutkan mengingat ikan nila GIFT merupakan hasil seleksi dengan sumber genetik ikan nila dari daerah Afrika. Satu hal yang mungkin menjadi penyebab fenomena ini adalah adanya genetic introgression pada populasi ikan nila di D. Tempe. Penyebab lainnya yang mungkin adalah ikan nila di D. Tempe berasal dari sumber genetik yang mempunyai kekerabatan dengan ikan nila dari Afrika. Haplotipe 1 yang diindikasikan merupakan asal sumber genetik ikan nila yang diuji, yang bercabang menjadi dua jenis haplotipe lainnya, haplotipe 2 dan 4 (Gambar 2). Jika keadaan ini yang terjadi maka ikan nila yang berada di Indonesia mempunyai potensi untuk dikembangkan serupa dengan nila GIFT hasil dari ICLARM. Dengan kata lain, penyebab merosotnya pertumbuhan ikan nila di Indonesia sebagian besar cenderung lebih disebabkan oleh belum sesuainya sistem manajemen yang digunakan.

Secara statistik dengan menggunakan AMOVA (Analysis Molecular Variance) menunjukkan bahwa tidak terdapat perbedaan genetik secara nyata antara populasi ikan nila yang diuji $(P>0,05)$. Hal ini berarti bahwa ikan nila GIFT yang ada di masyarakat masih berada dalam kondisi yang cukup baik (Tabel 2). Walaupun demikian, uji perbandingan berpasangan Fst mengindikasikan masih adanya perbedaan antara 


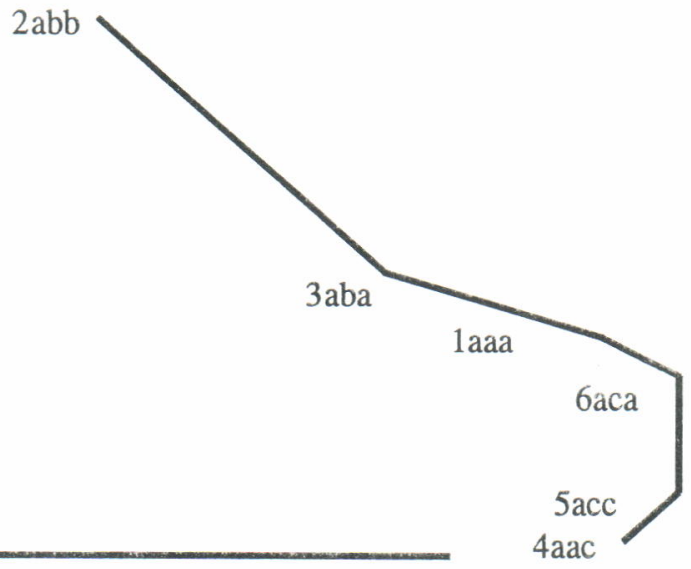

0.1

Gambar 2. Trees phylogram dari beberapa haplotype Mitokondria DNA D-loop ikan nila yang direstriksi dengan menggunakan 3 jenis enzim, MboI, Hae III, dan HinfI

Figure 2. Trees phylogram of Mitokondria DNA D-loop of Tilapia degenerated using 3 endonucleases, Mbol, Hae III, and HinfI

Tabel 2. Hasil AMOVA (Analysis of Molecular Varian) antara koleksi ikan nila

Table 2. AMOVA (Analysis of Molecular Varian) among Tilapia collections

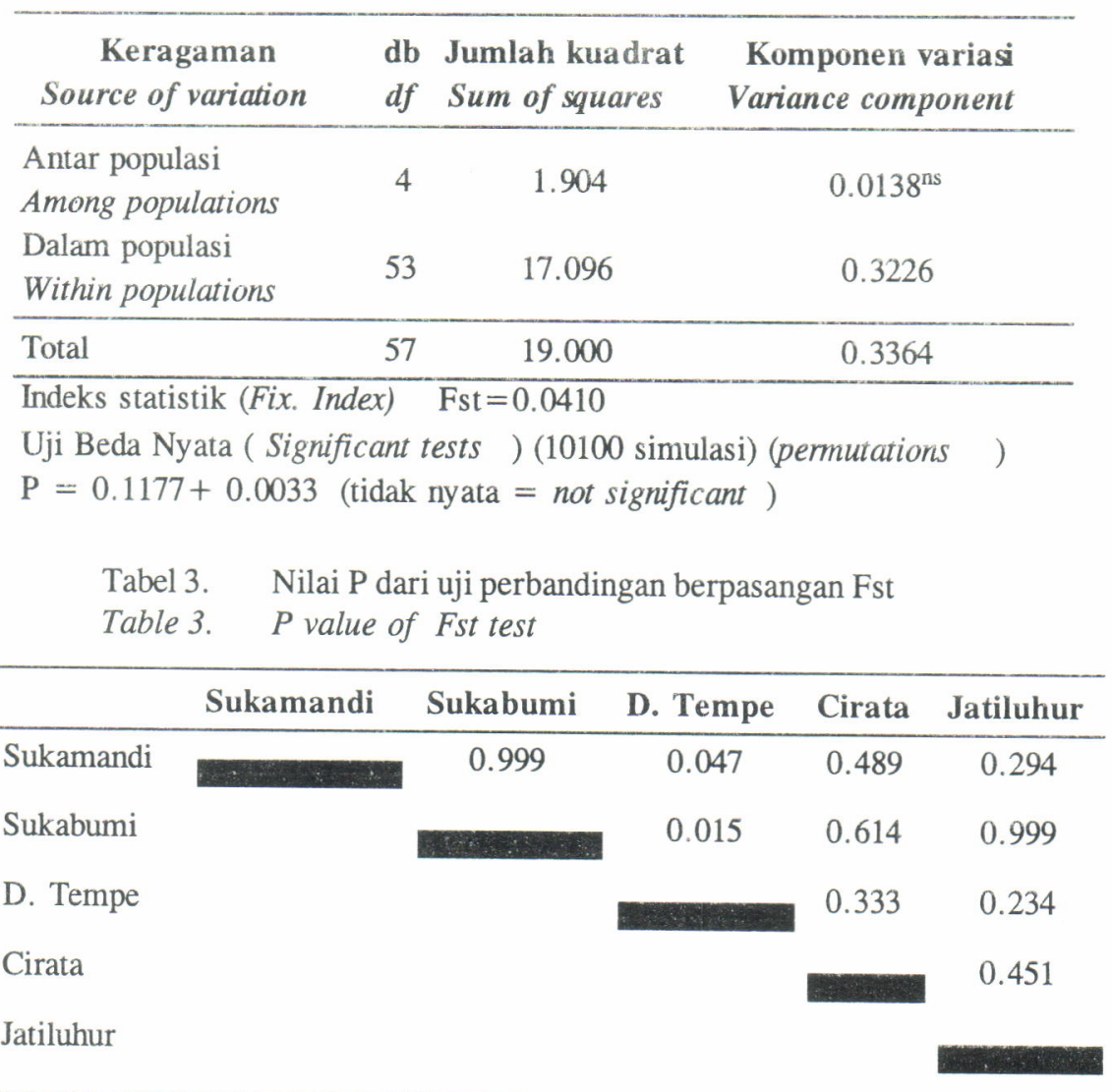

populasi ikan nila D. Tempe vs Sukamandi, serta D. Tempe vs Sukabumi pada taraf $\mathrm{P}<0,05$ (Tabel 3). Perbedaan antara nila 1969 (D. Tempe) dengan nila GIFT Sukamandi dan Sukabumi kemungkinan adanya pengaruh adaptasi terhadap lingkungannya, yang mungkin disebabkan oleh haplotipe 4.
Jarak genetik yang dihitung menurut Nei (1972) berdasarkan situs restriksi dari 3 enzim antara koleksi ikan nila tertera pada Tabel 4. Jarak genetik rata-rata antara populasi ikan nila adalah sekitar 0,0178. Dendrogram yang dibentuk berdasarkan jarak genetik tersebut menunjukkan bahwa koleksi nila dari 
Tabel 4. Jarak genetik Nei antara koleksi beberapa ikan nila GIFT dan 69 Table 4. Nei Genetic Distance among GIFT Tilapia and 69 collections

\begin{tabular}{lccccc}
\hline & Sukamandi & Sukabumi & D. Tempe & Cirata & Jatiluhur \\
\hline Sukamandi & & 0.0034 & 0.0204 & 0.0068 & 0.0286 \\
Sukabumi & & & 0.0178 & 0.0041 & 0.0259 \\
D. Tempe & & & & 0.0137 & 0.0356 \\
Cirata & & & & & 0.0218 \\
Jatiluhur & & & & & \\
\hline
\end{tabular}

Gambar 3. UPGMA dendogram dari beberapa koleksi ikan nila GIFT dan nila 69 Figure 3. UPGMA dendogram of GIFT Tilapia and 69 collections

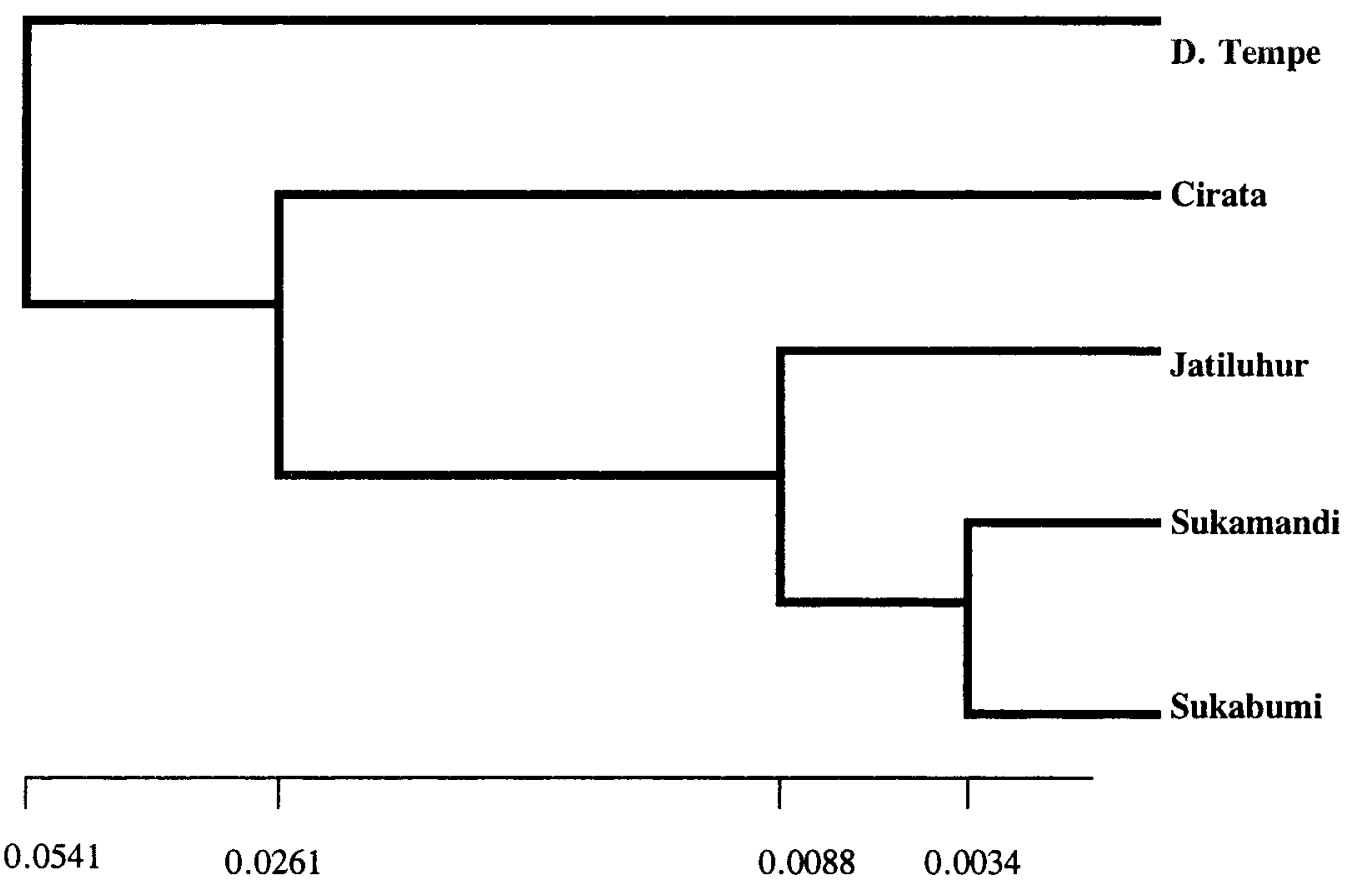

Gambar 3. UPGMA dendrogram dari beberapa koleksi ikan nila GIFT dan nila 69

Figure 3. UPGMA dendrogram of GIFT Tilapia and 69 collections

Sukamandi, Sukabumi, dan Jatiluhur mempunyai kekerabatan yang relatif lebih dekat dibandingkan dengan kekerabatan antara ketiganya dengan ikan nila dari D. Tempe dan atau Cirata (Gambar 3). Nilai kekerabatan ini dipengaruhi oleh asal sumber ikan nila GIFT yang digunakan serta penyebarannya, di mana ikan nila GIFT pertama kali diimpor oleh Balitkanwar Sukamandi dan disebarkan ke Sukabumi, Jatiluhur, dan Cirata. Namun pada perkembangannya, kemungkinan ikan dari Cirata telah beradaptasi dengan lingkungannya sehingga kehilangan haplotipe yang jarang (rare haplotype). Sedangkan jauhnya kekerabatan antara ikan nila $D$. Tempe dengan ikan nila dari lokasi lainnya mungkin disebabkan oleh adanya haplotipe 4 yang cukup mendominasi pada ikan nila D. Tempe yang tidak terdapat pada populasi lainnya.

\section{KESIMPULAN}

Tidak terdapat perbedaan genetik yang nyata antara populasi ikan nila yang diuji. Ada indikasi hilangnya beberapa haplotipe yang jarang seiring dengan perkembangan waktu dan penyebaran ikan nila.

\section{DAFTAR PUSTAKA}

Carvalho, G.R. and T.J. Pitcher. 1995. Molecular Genetics in Fisheries. Chapmann \& Hall, London. 255 pp. 
Ferguson, A.J., A.J. Taggart, P.A. Prodohl, O. McMeel, C. Thompson, C. Stone, P. McGinnity, and R.A. Hynes. 1995. The application of molecular markers to study and conservation of fish populations, with special refference to Salmo. Journal of Fish Biology. 47: 103$-126$.

Felstein, J. 1993. PHYLIP (PHYLogeny Interference Package), ver. 3.5c. Univ. of Washington, Seattle.

Martin, A.P., R. Humphreys, and S.R. Palumbi. 1992. Population genetic structure of the armorhead, Pseudopentaceros wheeleru, in the North Pacific Ocean : Application of the polymerase chain reaction to fisheries problems. Canadian Journal Fisheries Aquatic Science. 49: 2.386--2.391.

Nei, M and F. Tajima. 1981. DNA polymorphism detectable by restriction endonucleases. Genetics. 97: 145$-163$.

Nei, M. 1972. Genetic distance between populations. American Nature. 106: 283--292.
Nugroho, E., M. Takagi, and N. Taniguchi. 1997. Practical manual on detection of DNA polymorphism in fish population study. Bulletin of Marine Science and Fisheries. Kochi University, 17: 109--130.

Nugroho, E. 2001. Population Genetic Studies on the Aquaculture Fish in Genus Seriola for Their Risk Management. PhD Thesis. Tohoku University. 123 pp.

Park, L.K. and P. Morgan. 1995. Developments in molecular genetic techniques in fisheries. In Molecular Genetics in Fisheries by Carvalho, G.R and T.J. Pitcher (eds.) Chapmann \& Hall, London. p. 1--28.

Schneider, S., J.M. Kueffer, D. Roessli, and L. Excoffier. 1996. Arlequin: A Software Package for Population Genetics. Univ. of Geneva, Geneva, Switzerland.

Ward, R.D. and P.M. Grewe. 1995. Appraisal of molecular genetic techniques in fisheries. In. Molecular Genetics in Fisheries by Carvalho, G.R and T.J. Pitcher (eds.) Chapmann \& Hall, London. p. 55--80 